ACTA UNIVERSITATIS WRATISLAVIENSIS No 3985

Slavica Wratislaviensia CLXXII • Wrocław 2020

https://doi.org/10.19195/0137-1150.172.3

Data przesłania artykułu: 17.04.2019

Data akceptacji artykułu: 8.07.2019

DOMINIKA JANCZURA

Uniwersytet im. Adama Mickiewicza w Poznaniu, Polska

\title{
Ономастикон Кобзаря: поширені типи поетонімів та їхне функційне навантаження (до 205-ої річниці від дня народження Тараса Шевченка)
}

Тарас Григорович Шевченко - український поет, художник, історик, філософ, революціонер, символ української нації. 2019 року відзначено 205-у річницю від дня його народження, а життя і творчість цього генія досі викликають великий інтерес. Митрополит Іларіон писав, що Тарас Шевченко „перший у нас глибоко зрозумів вагу літературної мови в письменстві, i тому творив iï, пильнуючи, щоб вона була якнайкращою"”. Поета справедливо вважають основоположником нової української літератури та засновником сучасної української літературної мови, пророком свободи й незалежності України. Його творчість має сьогодні чимале значення для формування та зміцнення національної ідентичності, національної і мовної свідомості українців.

Шедевром творчості митця стала, як відомо, поетична збірка Кобзар, опублікована навесні 1840 року. Учені відзначають, що „високої майстерності досяг поет саме в жанрі лірики. Тут найповніше виражено думи й прагнення народу"2. Саме народність - провідна риса його творчості, що відповідно вербалізовано в мові, у всіх ії лексичних пластах. Народність і національний дух послідовно відбиті й в ономастиконі тексту Кобзаря, що $€$ предметом нашого дослідження.

\footnotetext{
1 М. Іларіон, Граматично-стилістичний словник Шевченкової мови, Вінніпег 1961, с. 5.

2 Шевченківський словник: у двох томах, т. І, Київ 1976, с. 18.
} 
На сьогодні літературна ономастика, хоч і наймолодший, але досить добре сформований напрям ономастики. Проте, на думку польських учених, зокрема Магдалени й Павла Графів ${ }^{3}$, сучасні ономасти більше зосереджують увагу на вивченні специфіки функціювання онімів у прозових текстах, а не в поетичних. Крім того, за спостереженнями зазначених дослідників, літературні оніми переважно інтерпретуються виключно в стилістичному аспекті 4 . Нові дослідження, виконані в руслі парадигми сучасної прагмалінгвістики, $\epsilon$ досить популярними. Досліджуючи ономастикон художніх текстів, польські науковці надають перевагу методологійним засадам сучасної лінгвістики тексту або здійснюють аналіз в історико-літературному контексті ${ }^{5}$. Магдалена й Павел Граф переконані, що автори наукових розвідок, присвячених поетонімам, прагнуть розв'язати насамперед теоретичні проблеми ономастики стосовно з'ясування межі між пропріативами й загальними назвами чи питання, пов'язані з природою значення власної назви ${ }^{6}$. Поетонім - це власна назва, що функціює в художньому тексті. Поетонімами, зрозуміло, можуть бути всі розряди онімів - i реальні, і вигадані уявою письменника. Цей термін був запропонований Валерієм Калінкіним ${ }^{7}$. Його використовують передусім представники Донецької ономастичної школи. На позначення онімів, що функціюють у художньому тексті, використовують й інші терміни. У наукових студіях представників Ужгородського ономастичного осередка, наприклад, функціює номінація літературно-художній онім (Л. Белей), засновник Одеської ономастичної школи Ю. Карпенко пропонує термін літературний онім. Деякі ономасти вважають термін поетонім не зовсім коректним, оскільки він викликає асоціації $з$ поетичним текстом (поетонім - поетичний онім, поетичний - поезія) і використовувати його доцільно в такому разі лише стосовно оніма, що функціює виключно в поетичному тексті, але не в текстах прозових. Оскільки ми досліджуємо особливості функціювання онімів в поезії Т. Шевченка, то вживання терміна поетонім в цій розвідці вважаємо виправданим.

Актуалізуючи методологію прагмалінгвістики, уважаємо за необхідне дослідити ономастикон Т. Шевченка в окресленому аспекті. Отже, мета цієї наукової студії — виявити прагматичні фукції поетонімів як елементів ономастикону, укладеного на основі поетичного тексту Кобзаря Т. Шевченка, та виокремити найбільш поширені типи онімів у зазначеному ономастиконі.

Хоча шевченкознавсто ${ }^{8}$ й належить до актуальних і добре розроблених на сьогодні напрямів української гуманітарної науки, однак питання функ-

${ }^{3}$ M. Graf, P. Graf, Nazwa w butonierce - wokót onimii tekstu poetyckiego (na przykładzie poezji Brunona Jasieńskiego), „Onomastica” 62, 2018, c. 16.

${ }^{4}$ Ibidem.

5 Ibidem, c. 17.

6 Ibidem.

7 Див. В. М. Калинкин, Поэтика онима, Донецк 1999.

8 Див. Г. Конторчук, Творчість Тараса Шевченка як об'єкт мовознавчих студій, http:// eprints.zu.edu.ua/11815/1/Конторчук\%202.pdf [доступ: 10.04.2019]. 
ціювання онімів у текстовому просторі Шевченка потребує ретельного вивчення. Зауважмо, що шевченківський ономастикон досліджувала Лариса Масенко ${ }^{9}$, топонімікон - Микола Фененко ${ }^{10}$, антропонімікон - Любомир Белей ${ }^{11}$, Віктор Чабаненко ${ }^{12}$, Ганна Конторчук ${ }^{13}$, Тетяна Черторизька ${ }^{14}$ та Іван Сухомлин ${ }^{15}$.

Наголосімо також, що в українській лінгвістиці вироблено традицію розглядати пропріативи як систему концептів (когнітивна ономастика), мотивовану відповідними асоціаціями, що виникають у мовній свідомості конкретного мовця чи мовного колективу загалом. Оніми — це дзеркало, що відображає традиції, фіксує факти історії, культуру народу. Вони, власне, й указують на національну чи культурну ідентичність людини. Поетоніми містять містку прагматичну інформацію, оскільки письменники добирають своїм персонажам імена з певною настановою. Такі „виразні” поетоніми часто підлягають апелятивізації, стаючи одночасно своєрідними символами культури конкретного мовного простору. Тетяна Космеда зауважує, що „основна відмінність культурної ономастики від загальномовної полягає саме у сфері прагматики, тобто стосується функціювання власних назв як знаків і символів культури"16. Згадаймо в цьому контексті й українського мовознавця Євгена Отіна, який уклав словник конотативних власних імен, поширених в українському соціумі ${ }^{17}$.

Магдалена й Павел Граф наголошують, що в просторі художнього тексту, незалежно від його жанрового типу, відсутні назви, що позбавлені значення, яке виявляється на різних етапах читання, тому кожен онім у тексті може бути функційно й семантично інтерпретований ${ }^{18}$. На нашу думку, значення поетоніма, як і всіх інших онімів, має прагматичну природу (М. Толстой).

9 Див. Л. Т. Масенко, Власна назва у поетиці Т. Шевченка, „Культура слова” 1989, вип. 37.

10 Див. М. В. Фененко, Топоніміка Украӥни в творчості Тараса Шевченка, Київ 1965.

11 Див. Л. Белей, Тарас Шевченко як засновник нової украӥнської літературно-художньої антропонімії, [в:] VII Міжнародний конгрес україністів „Мовознавство”, ред. Г. Скрипник, Київ 2015, с. 11-21.

12 Див. В. А. Чабаненко, Антропоніми в Шевченкових поезіях, ред. Є. П. Кирилюк, Київ 1973, c. 141-156.

13 Див. Г. К. Конторчук, Біблійні антропоніми у поемах Т. Шевченка, доповідь під час Міжнародної наукової конференції „Спадщина Т. Шевченка як націєтворчий чинник” в 2003 року в Інституті філології Киівського національного університету імені Тараса Шевченка.

14 Див. Т. К. Черторизька, Літературні антропоніми у творах Т. Г. Шевченка, „Мовознавство” № 2, 1989, с. 28-34.

15 Див. І. Д. Сухомлин, Прізвища та їх функиії в поезіях Т. Г. Шевченка, [в:] Питання стилістики української мови в ї̈ взаємозв'язку з іншими слов'янськими мовами, редкол. Ю. О. Карпенко, В. І. Кузнецов, І. І. Слинько, Чернівці 1963, с. 68-70.

16 Т. А. Космеда, Ego i Alter Ego Tapaca Шевченка в комунікативному просторі щоденникового дискурсу, Дрогобич 2012, с. 251.

17 Див. Е. С. Отин, Словарь коннотативных собственных имен, 3-е изд., перераб. и доп., Донецк 2010, 318 с.

18 M. Graf, P. Graf, Nazwa w butonierce..., c. 17. 
Письменники ж, звісно, добирають імена своїм персонажам так, щоб вони могли викликати відповідні асоціації, впливати на думки читачів і формувати їх, підсилювати зміст написаного, викликати певні емоції.

Як засвідчує аналіз, текст Кобзаря насичений різноманітними поетонімами, серед яких: 1) антропоніми (Богдан, Степан, Котляревський, Собієський тощо), 2) ергоніми (Кравчина, Лебедин тощо), 3) етноніми (ляхи, поляки, шве$\partial и$ тощо), 4) космоніми (Діана), 5) теоніми (Зевс, Кіпріда, Христос тощо), 6) топоніми: ойконіми (Варшава, Київ, Москва тощо), гідроніми (Дніпро, Дон тощо), ороніми (Урал), хороніми (Україна, Польща), 7) фіктоніми (Ганна, Катерина, Марко, Оксана, Ярема тощо), 8) хрематоніми (Вибла могила, Віфлеємська каплиия тощо), 9) хрононіми (Колї̈виина, Покрова, Маковеїв день).

Серед ужитих у тексті розглядуваної поетичної збірки пропріативів за авторськими підрахунками найбільшу кількість становлять топоніми (167 одиниць). Численними є антропоніми (142 од.) та фіктоніми (46 од.) (див. Діаграма 1). Василь Яременко зауважує, що „переважання топонімів $є$ цілком закономірною ознакою [...]. Звертаючись до минулого, зокрема 3 метою ідентифікації українців, він мав спершу „маркувати” певну територію, а вже потім „заселяти” цей географічний простір конкретними людьми”19. Ураховуючи, що в тексті аналізованої поетичної збірки виявлено велику кількість онімів, розглянемо тільки найчастотніші власні назви.

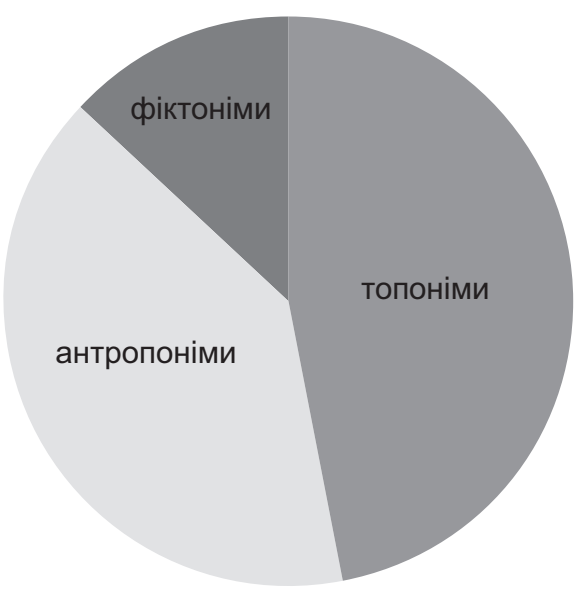

Діаграма 1. Співвідношення найбільш частотних типів онімів у поетичній збірці Т. Шевченка Кобзар.

19 В. І. Яременко, Історична ономастика у творчій спадщині Тараса Шевченка, „Український історичний журнал” 2010, № 2, с. 170, dspace.nbuv.gov.ua:123456789/105072 [доступ: 13.04.2019]. 


\section{Топопоетоніми}

До найбільш частотних топопоетонімів належать Україна, Дніпр і Київ. Онім Україна функціює в тексті і в таких формах (варіантах), як Украйна, Вкраїна, порівн.: Тілько сльози за Украйну... (Думи мої, думи мої); У нас на Вкраӥні (Утоплена). Україна - батьківщина Шевченка, і саме цей онім віддзеркалює образ „країни-матері”. Аналізований поетонім інтимізований завдяки використанню присвійних займенників, порівн.: Моя Україно! (Думи мої, думи моі); Нехай свою Украӥну / Я ще раз побачу (До Основ'яненка). Розглядуваний топонім, окрім емоційно-стилістичної функції, виконує також інформаційно-стилістичну й історіографічну, оскільки Україна — назва країни, держави, що має відповідний статус - політику, мешканців, історію, культуру і под.

Дніпр - власна назва найдовшої річки України. У тексті Кобзаря функціює також іiї орфографічний варіант Дніпро, порівн.: Реве та стогне Дніпр широкий (Причинна); I Дніпро спустила (Сон). Дніпр - своєрідний символ Української держави, частина її історії. Його важливість, сила й могутність виражаються завдяки використанню епітета широкий, порівн.: Дніпр широкий - море (Думи мої, думи моі). Наведений пропріатив також інтимізований: у тексті орнаменталізується - уособлюється, напр.: Дніпро, брат мій (Розрита могила). Указаний поетонім емоційно навантажений, тому, окрім інформаційної функції, виконує й емоційно-стилістичну.

Київ - одне з найстарших і найбільших міст Європи, столиця України, а також давньої держави - Київської Русі. У тексті Кобзаря цей онім функціює здебільшого на позначення релігійного осередку, порівн.: Посилає в Київ / Мене, бачиш, молитися. (Відьма); Пішов собі тихо в Київ / Святим помолитись (Варнак). Його релігійна значущість підсилюється прикметником святий, що має сакральне значення, порівн.: Святий Київ наи великий (Варнак); I ввесь святий Київ (Чернець). В. Яременко вважає, що „топонімія Кобзаря була спрямована на формування єдиного, цілісного образу України та українського народу, зокрема й за рахунок набуття спільної історичної пам'яті" 20 . Підтримуємо думку цього дослідника в тому, що „в текстах Т. Шевченка простежується тенденція до утвердження саме української форми ойконімів та гідронімів - не тих, які були привнесені й закріплені в книжно-офіційному, канцелярському вживанні, а тих, які етимологічно й семантично $€$ точнішими, оскільки історично успадковувалися місцевою людністю та усталювалися народним мовленням" 21 .

20 Ibidem, c. 167.

21 Ibidem. 


\section{Антропопоетоніми}

Серед антропонімів найбільш частотними є Залізняк Максим (кількість уживань - 48), Гонта (30 випадків уживання), Богдан (кількість уживань 21), Іван Гус (17 випадків уживання).

Онім Залізняк Максим функціює в тексті як „тільки ім'я” або „тільки прізвище”. Максим Залізняк - запорізький козак, один з керівників народного повстання проти польського гніту на Правобережній Україні ${ }^{22}$. Аналізований поетонім (ім'я Максим) використаний у тексті з іменником батько, напр.: У нас один старший - батько Максим, що вербалізує інтимний смисл, оскільки батько - символ поваги, шани, любові.

Іван Гонта - сотник уманського надвірного козацтва, який служив при дворі, один з керівників народного повстання проти польського гніту на Правобережній Україні ${ }^{23}$. Наведений пропріатив функціює в тексті також у назві твору Гонта в Умані. Значення розглядуваного оніма інтимізується через актуалізування займенника той, порівн.: Один буде, як той Гонта (Beликий льох). Це, на думку Леоніда Булаховського, типовий засіб інтимізації в шевченківському тексті ${ }^{24}$.

Онім Богдан однозначно асоціюється з гетьманом Хмельницьким - видатним українським державним діячем, полководцем. Одиниця Богдан функціює як прецедентне ім'я, тому в тексті воно вжите й без прізвища. Аналізована власна назва супроводжується прикметником-епітетом славний, що використаний у функції оцінки його діяльності у визвольній боротьбі українського народу, напр.: Останок славного Богдана (Свято в Чигирині). Значущість особистості актуалізована також через прийом „оспівування” його імені, напр.: Йили в $C y$ ботов про Богдана / Мирянам співати. (Великий льох). Зміст розглядуваного оніма також інтимізований: у тексті використано зменшено-пестливу форму цього імені - Богданчик, порівн.: Ой Богдане, Богданочку! (Розрита могила). Додаймо, що актуалізоване й церковне ім'я Хмельницького - Зіновій, порівн.: Отаке-то, Зіновію, / Олексїв друже! (Стоїть в селі Суботові...), що підсилює мотив сакральності, показує значення релігії для українського народу.

Іван Гус - чеський герой Ян Гус. Замість офіційної форми західнослов'янського імені Ян Т. Шевченко в Кобзарі вживає його східнослов'янський відповідник Іван, що виражає прагнення митця зробити цього героя ближчим до українського читача. Указана власна назва функціює в тексті з прикметниками славний і великий, що, відповідно, несуть емоційне навантаження - виражають позитивне ставлення Шевченка до реформаторської діяльності Гуса.

22 Шевченківський словник..., с. 413.

23 Ibidem, c. 290.

24 Див. Л. А. Булаховський, Мовні засоби інтимізаиії в поезї Тараса Шевченка, [в:] idem, Вибрані прачі: в 5 томах, т. 2, Київ 1977, с. 573-594. 


\section{Фіктопоетоніми}

Для тексту Кобзаря найбільш характерними є фемінні фіктоніми Оксана й Катерина. Це улюблені жіночі імена письменника.

Ім'я Оксана отримує в Т. Шевченка конотативний ореол, „супроводжується" відповідними інтимізованими займенниковими формами, уживається в пестливій формі, актуалізоване в подвійному звертанні, порівн.: Oта Оксаночка? (Ми в купочиі колись росли); Та безталанную мою, / Мою Оксаночку? (Не молилася за мене...); ,,Оксано, Оксано!'” (Червоний бенкет). Ім’я Оксана відображає характерні риси українки (зокрема, сердечність, здатність кохати, ніжність, турботливість), тому й має позитивний конотативний ореол. Катерина, Катруся, Катря - у перекладі з грецької означає 'чиста', 'чистота'. Етимологічне значення наведеного оніма відповідає рисам характеру героїні збірки - невинної, простодушної і наївної. Ім'я Катерина використано в назві однієї з поем Т. Шевченка, тобто в сильній текстовій позиції, що має особливу прагматику. Зміст аналізованого поетоніма відповідно інтимізований актуалізуванням щодо нього присвійного займенника мій та метафори серие, наприклад: Катерино, серие моє! (Катерина). Інтимізацію створюють також указівні займенники та, оия і под., порівн.: У тієї Катерини (У тієі Катерини...); Оиій Катерині (У тієї Катерини...), які, як наголошувалося вище, дослідники кваліфікують як шевченківські засоби інтимізування тексту. Додаймо, що до імені Катерина Тарас Шевченко ставиться по-особливому, оскільки це власне українське ім'я, реальний народно-розмовний онім. Крім того, саме так звали матір і сестру поета. Безсумнівно, аналізований поетонім містить велике емоційне навантаження.

Отже, власні назви, ужиті в поетичному тексті Кобзаря, виконують, крім власне номінативної функції для позначення відповідних реальних об'єктів довкілля, ще й низку прагматичних функцій, серед яких: 1) текстотвірну, оскільки пропріативна лексика в художньому тексті дає змогу читачеві розпізнати текстові стратегії автора: щоб зрозуміти текст, потрібно дешифрувати значення онімів; 2) аксіологічну, тому що вживання конкретного оніма у відповідній формі може підсилювати негативне або позитивне враження, репрезентувати відповідні позитивні чи негативні емоції; 3) $x y$ дожню, оскільки використання відповідної назви супроводжується орнаментальними мовними засобами, насамперед, як показує наведений матеріал, семантичними відтінками епітетів; 4) символічну, оскільки поетонім може виступати певним символом (національним, культурним, державним і под.); 5) асоціативну, оскільки поетонім актуалізує систему відповідних вражень, образів, асоціацій, що залежить від авторського задуму й фонового, що міститься в мовній свідомості читачів (насамперед ідеться про актуалізування прецедентних імен); 6) інтимізувальну, адже використання того чи того оніма, зокрема з актуалізуванням відповідної інтимізованої форми чи в поєднанні з інтимізувальними словами (насамперед прикметниками, за- 
йменниками, частками) може викликати в читачів почуття симпатії, теплоти, дружнього ставлення; 7) атракційну, оскільки виразна власна назва, близька читачам з тієї чи тієї причини, привертає особливу увагу, зокрема, коли використовується в сильних текстових позиціях.

\section{Висновки}

Ономастикон Кобзаря утворюють різноманітні власні назви, серед яких найбільше топонімів, антропонімів і фіктонімів. Обрані Т. Шевченком оніми, як показує аналіз, містять вагому прагматичну інформацію й виконують систему функцій.

Найбільш частотні в тексті Кобзаря топопоетоніми - це ключові для мовної свідомості поета найменування, близькі його серцю: Україна, Київ $i$ Дніпро. Указані оніми належать до символів української нації. Наведені оніми виконують, окрім суто називної функції, що має на меті надати історикографічну інформацію, розмістити текст на географічній карті, дати уяву про факти, ще й емоційно-стилістичну функцію. Вони покликані формувати в читачів відповідні асоціації, почуття, підсилювати текстову прагматику. Використовуючи близькі йому оніми, поет відповідно їх інтимізує, моделює оригінальну орнаменталіку.

Не менш значущу роль у шевченківському тексті відіграють антропопоетоніми, серед яких найчастотнішими є Максим Залізняк, Гонта, Богдан, що містять актуальну для української нації інформацію, оскільки належать до прецедентних імен української історії. Автор інтимізує їх, омовлюючи власні емоції й почуття, симпатію й позитивну оцінку, інколи навіть їх сакралізуючи.

Найбільш виразними фіктонімами у розглядуваній поетичній збірці є фемінні власні назви Оксана й Катерина. Вибір імен персонажів однозначно не випадковий, пов'язаний $з$ українськими традиціями іменування, етимологією, внутрішньою формою імені, авторськими біографічними фактами, його симпатіями, що актуалізує відповідні конотації.

Оніми, ужиті в поетичній збірці Кобзаря, поліфункційні. Окрім суто інформаційної функції, шевченкові оніми виконують, як було показано, низку прагматичних функцій, що мають на меті підсилювати текстову експресію, збагачувати його додатковими конотаціями, допомогти читачеві відповідно сприйняти й зрозуміти текст. 3 огляду на значущість Тараса Шевченка для українського народу, ономастикон його поетичних творів заслуговує на більш детальне й комплексне дослідження. 


\section{Бібліографія}

Âremenko V. İ., İstorična onomastika u tvorčì spadŝini Tarasa Ševčenka, „Український історичний журнал” 2010, № 2, c. 170, oai:dspace.nbuv.gov.ua:123456789/105072.

Belej L., Taras Ševčenko âk zasnovnik novoï ukraïns'koï literaturno-hudožn'oï antroponimï̈, [v:] VII Mižnarodnij Kongres Ukraïnistiv ,, Movoznavstvo”, red. G. Skripnik, Vidavnictvo İMFE, Kiïv 2015.

Bulahovs'kij L. A., Movnì zasobi intimizacï v poezï Tarasa Ševčenka, [v:] idem, Vibranì pracì, v 5 tomah, t. 2, Naukova dumka, Kiïv 1977.

Čabanenko V. A., Antroponìmi v Ševčenkovih poeziâh, Zbìrnik prac' dvadcâtoï naukovoï ševčenkìvs'koï konferenciï, red. Ê. P. Kirilûk, Naukova dumka, Kyïv 1973.

Čertoriz'ka T. K., Literaturnì antroponimi u tvorah T. G. Ševčenka, „Movoznavstvo” № 2, 1989.

Fenenko M. V., Toponimika Ukraïni v tvorčostì Tarasa Ševčenka, Radâns'ka škola, Kyïv 1965.

Graf M., Graf P., Nazwa w butonierce - wokół onimii tekstu poetyckiego (na przykładzie poezji Brunona Jasieńskiego), „Onomastica” 62, 2018.

İlarìon M., Gramatyčno-stylistyčnij slovnyk Ševčenkovoji movy, Nakladom Tovaristva „Volin”” v Vìnnìpezì, Vìnnìpeg 1961.

Kalinkin V. M., Poètika onima, Ûgo-Vostok, Doneck 1999.

Kontročuk G., Tvorčìst' Tarasa Ševčenka âk ob 'êkt movoznavčih studij, http://eprints.zu.edu.ua/11815/1/ Kontorčuk\%202.pdf.

Kosmeda T. A., Ego i Alter Ego Tarasa Ševčenka v komunikatyvnomu prostorì sodennykovogo dyskursu, „Kolo”, Drogobič 2012.

Masenko L. T., Vlasna nazva u poeticì T. Ševčenka, „Kul'tura slova” 1989, vip. 37.

Otin E. S., Slovar' konnotativnyh sobstvenny imen, 3-e izd., pererab. i dop., Ûgo-Vostok, Doneck 2010. Ševčenkivs'kyj slovnyk u dvoh tomah, t. 1, Kyïv 1976.

Suhomlin İ. D., Prìzvisia ta ïh funkciï v poezîah T. G. Ševčenka, [v:] Pitannâ stilistiki ukraïns'koï movi viï vzaêmozv âzku z inšimi slov'âns'kimi movami: tezi dop. mižvuz. nauk. konf., redkol. Û. O. Karpenko, V. İ. Kuznecov, İ. İ. Slin'ko, Vidavnictvo ČDU, Černìvcì 1963.

\section{Onomastics of Kobzar: Widespread types of poetic proper names and their functional load (dedicated to the 205th anniversary of Taras Shevchenko's birth)}

\section{Summary}

The present article is devoted to the issue of literary onomastics, which is an essential topic in modern Ukrainian linguistics. The study is focused around the textual space of Kobzar, Taras Shevchenko's poetry collection. The aim of the article is to investigate the structure of the onomasticon in this collection, and to identify the peculiarities of the functioning of proper names as related to their pragmatic load. It is concluded that the Kobzar onomasticon is composed of a variety of proper names, the majority of which are toponyms, antroponyms and fictional names. The proper names used in Kobzar serve not only a nominative function, which consists in designating the relevant real-life objects in the environment, but also textual, axiological, artistic, symbolic, personalizing and attractional functions.

Keywords: literary onomastics, onomasticon, proper name, pragmatic information, functional load

Slavica Wratislaviensia 172, 2020

(C) for this edition by CNS 


\section{Onomastykon Кобзаря [Kobziarza] - rozpowszechnione typy poetonimów oraz ich funkcjonalne nacechowanie (z okazji 205. rocznicy urodzin Tarasa Szewczenki)}

\section{Streszczenie}

Niniejszy artykuł jest poświęcony zagadnieniu onomastyki literackiej, będącej ważną subdziedziną współczesnego językoznawstwa ukraińskiego. Celem opracowania jest przedstawienie struktury onomastykonu zbioru poezji Tarasa Szewczenki Кобзар [Kobziarz] oraz ukazanie osobliwości funkcjonowania onimów z uwzględnieniem ich nacechowania pragmatycznego. Onomastykon zbioru poezji Кобзар tworzą różne nazwy własne, z czego większość to toponimy, antroponimy i imiona fikcyjne. Nazwy własne użyte w badanym tekście, oprócz prymarnej funkcji nominatywnej, w celu identyfikacji konkretnych realnych obiektów otoczenia pełnią również funkcję tekstotwórczą, aksjologiczną, artystyczną, symboliczną, asocjacyjną, personalizującą oraz funkcję uatrakcyjnienia.

Stowa kluczowe: onomastyka literacka, onomastykon, onim, znaczenie pragmatyczne, nacechowanie funkcjonalne 